\title{
The Age of the Sept Iles Layered Mafic Intrusion, Canada: Implications for the Late Neoproterozoic/Cambrian History of Southeastern Canada ${ }^{1}$
}

\author{
Michael D. Higgins and Otto van Breemen ${ }^{2}$ \\ Sciences de la Terre, Université du Québec à Chicoutimi, Chicoutimi, \\ G7H 2B1, Canada; mhiggins@uqac.uquebec.ca
}

\begin{abstract}
The large Sept Iles layered mafic intrusion of eastern Canada has been precisely dated by U-Pb zircon methods at 565 $\pm 4 \mathrm{Ma}$. Consideration of other magmatic events at that time in southeastern Canada reveals three different phases of magmatism. The first phase was composed of two tholeiitic dike swarms, at $615 \mathrm{Ma}$ and $590 \mathrm{Ma}$. The second, including the Sept Iles intrusion, comprised a widespread series of mostly alkaline intrusions, emplaced around 575$565 \mathrm{Ma}$, along the rift faults of the St Lawrence graben. The last phase was composed predominantly of alkali and transitional basalts, now exposed in the Appalachians, erupted during the latest Neoproterozoic and early Cambrian. The second and third phases are best accounted for by the arrival of a major mantle plume near the town of Sept Iles 565 million years ago. The widespread, but volumetrically minor, alkali magmatism that peaked $10 \mathrm{~m} . \mathrm{y}$. earlier is typical of other plumes elsewhere. The plume model is reinforced by sedimentological evidence for a crustal dome centered near the town of Sept Iles that persisted for $80 \mathrm{~m}$.y. The positions of the earlier dike swarms are problematical. They may represent vertical and/or lateral transport of magmas into the crust from earlier independent plumes or precursors to the Sept Iles plume.
\end{abstract}

\section{Introduction}

The period around the Neoproterozoic-Cambrian boundary was a time of breakup of a supercontinent and the formation of the Iapetus Ocean (e.g., Bond et al. 1984; Ilyin 1990; Piper 1976). Just exactly when the eastern margin of Laurentia began to rift has been the subject of much speculation: Kamo et al. (1989) suggested $615 \mathrm{Ma}$, based on diabase dikes from Labrador and Newfoundland (figure 1), whereas Kumarapeli (1993) favored $590 \mathrm{Ma}$, the age of a diabase dike swarm in Ontario and Quebec (Kamo et al. 1989). Farther south Aleinikoff et al. (1995) considered that breakup occurred at 560-570 Ma. However, as will be shown here the most widespread igneous event, and volumetrically the most important, was around 575-565 Ma. Lavas associated with the rift-drift transition appeared shortly afterward (Kumarapeli 1993). The purpose of this article is to integrate these ages with new geochronological data from the Sept Iles intrusion into

\footnotetext{
${ }^{1}$ Manuscript received April 24, 1997; accepted January 22, 1998.

${ }^{2}$ Geochronology laboratory, Geological Survey of Canada, 601 Booth St., Ottawa, K1A 0E8, Canada.
}

a coherent model for the formation of the Iapetan plate margin using plume models (Campbell and Griffiths 1990; White and McKenzie 1989).

\section{Sept Iles Intrusion}

The Sept Iles intrusion, a major feature on gravity and magnetic maps of eastern North America, is relatively unknown as it is mostly concealed beneath the waters and sediments of the Gulf of St. Lawrence (figure 1). However, the northwestern part of the intrusion crops out on six major islands, a peninsula, and the mainland (figure 2, Higgins and Doig 1981). An age of $540 \pm 10 \mathrm{Ma}$ for the Sept Iles intrusion was initially determined by Higgins and Doig (1981) using Rb-Sr isochrons from the syenitic and granitic parts of the intrusion and from granophyric segregations in the anorthositic rocks. This age established that the Sept Iles intrusion is younger than most of the rocks of the Grenville Province and was in fact associated with the formation of the St. Lawrence Rift system (Kumarapeli and Saull 1966). 


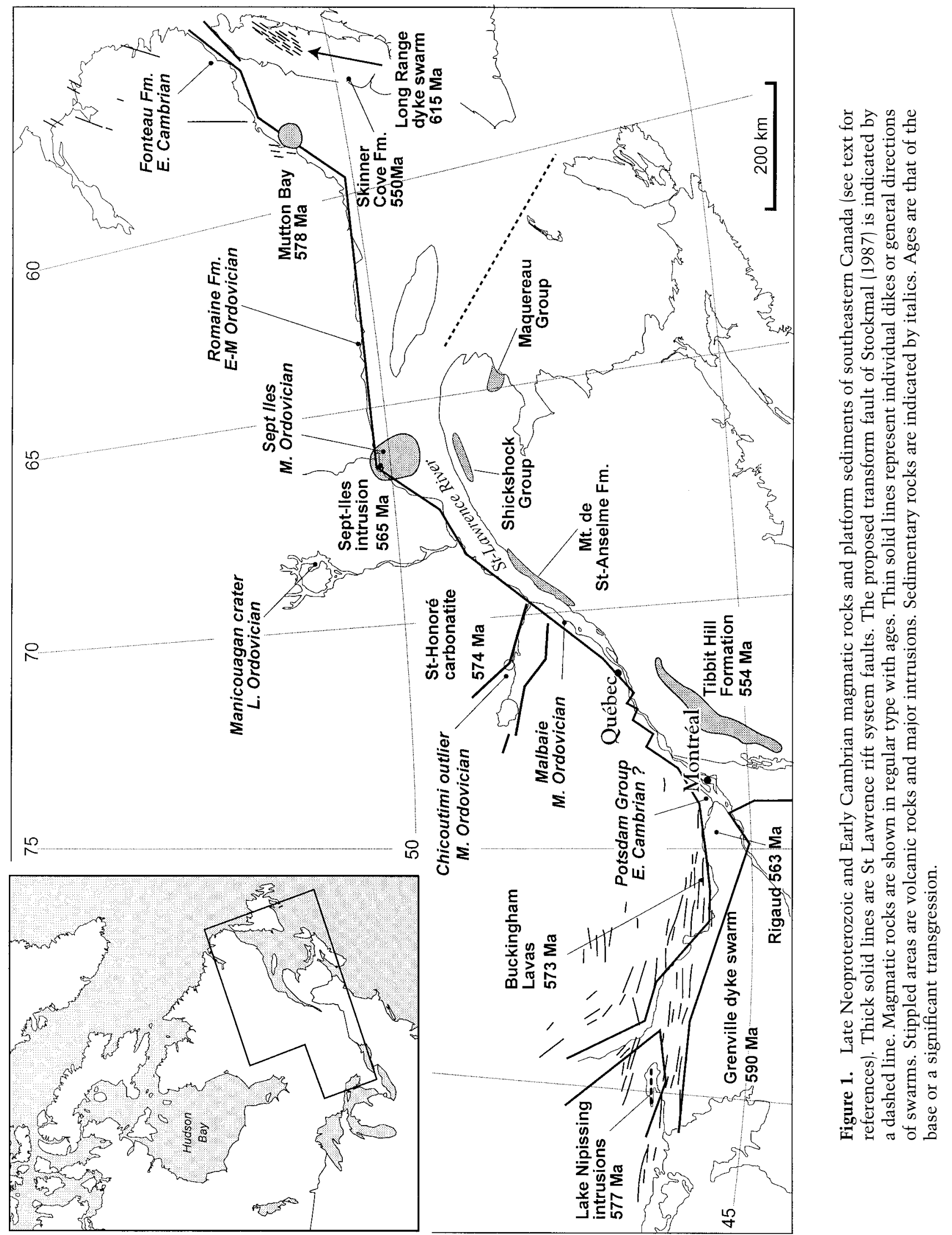




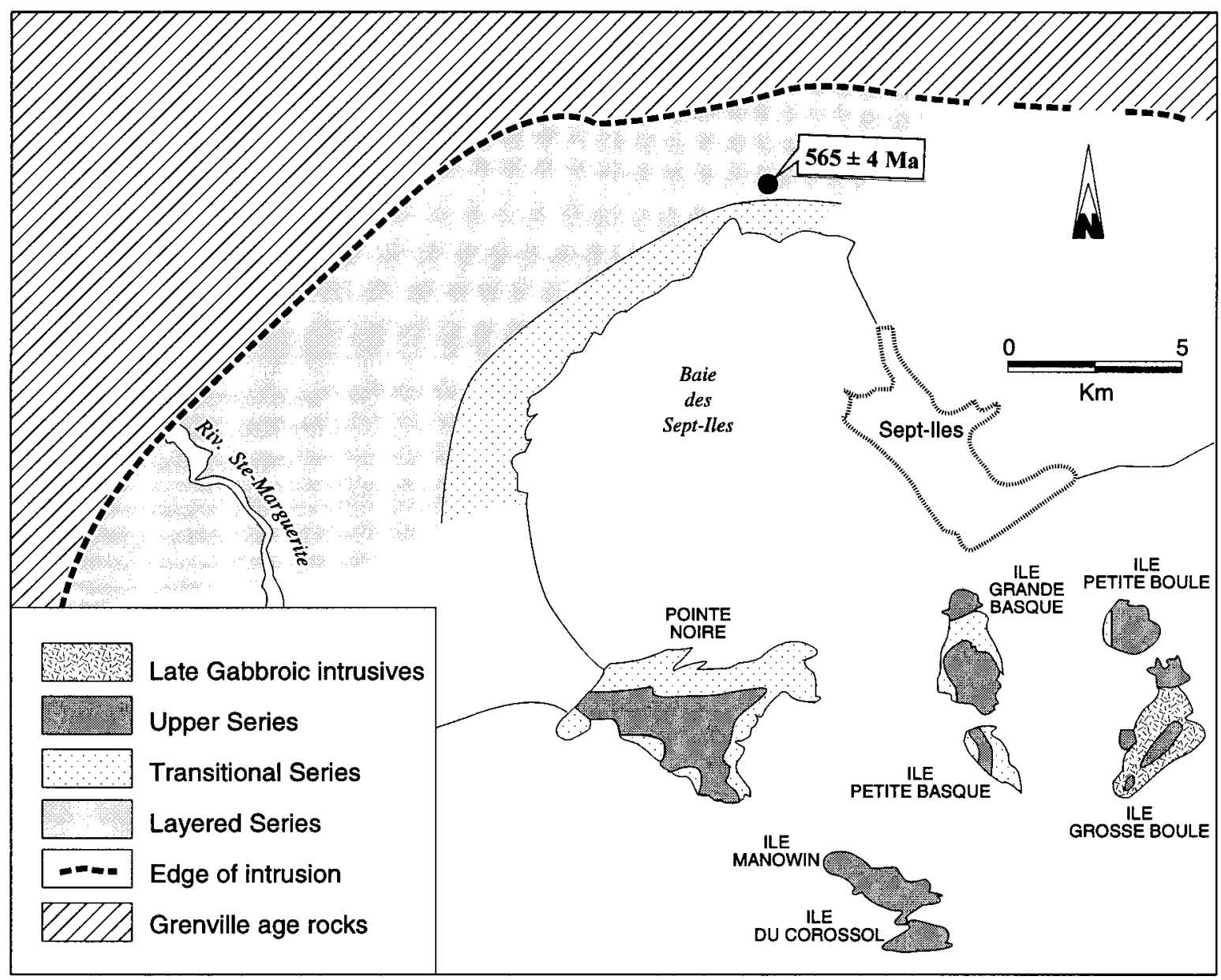

Figure 2. The Sept Iles layered mafic intrusion, eastern Canada (after Higgins and Doig 1981, Jules Cimon pers. comm., and other sources). The location of the sample used for geochronology is noted.

Early work on the Sept Iles intrusion suggested that it was an anorthosite complex (Higgins and Doig 1977), similar to the Proterozoic Anorthosite Complexes (PAC) in the Grenville Province and elsewhere (Ashwal 1993). This idea was based on the petrology and field relationships of the anorthositic parts of the intrusion, which do resemble those of the Grenville PAC. However, recent detailed geophysical and drilling studies have shown that the overall composition of the Sept Iles intrusion is oxide-rich gabbro (Loncarevic et al. 1990; Jules Cimon pers. comm.), not the gabbroic-anorthosite of the PAC (Ashwal 1993). Sr isotopes also indicate a fundamental difference: All components of the Sept Iles intrusion have a mantle source (Higgins and Doig 1981), whereas most parts of the PAC have heavily contaminated mantle or crustal sources (Ashwal 1993). All these data indicate that the Sept Iles intrusion is completely different from the PAC of the Grenville Province.

Geology of the Intrusion. Geophysical studies in- dicate that the Sept Iles intrusion has the form of a funnel about $80 \mathrm{~km}$ in diameter and about $5.6 \mathrm{~km}$ thick in the center, with a total volume of about $20,000 \mathrm{~km}^{3}$ (Loncarevic et al. 1990). The body was emplaced into high-grade gneisses of the Grenville Province and is centered at the intersection of two of the fault zones that define the northern boundary of the St Lawrence Rift in this area (figure 1, Kumarapeli and Saull 1966). The only evidence for a third rift that would produce a RRR triple junction at Sept Iles is an aeromagnetic anomaly that extends northward for $50 \mathrm{~km}$ (Geological Survey of Canada 1969) and an alignment of deep river valleys in the same direction.

The position of the Sept Iles intrusion could also be related to another structure, the $\sim 400 \mathrm{~km}$ long transform fault postulated to have offset the rifted margin of Laurentia (Stockmal et al. 1987). This structure extends from north of Cape Breton to east of the Gaspé peninsula. However, the fault may continue as far as Sept Iles, which may account for 
the poor expression, or absence, of the northern branch of the triple junction.

The Sept Iles intrusion is composed of three rock series, each variable in composition. At the base is the Layered Series, composed of layered gabbros some rich in oxides and/or apatite, minor anorthosite, troctolite, and Fe-Ti oxide rocks. The rocks of this series typically dip at about $30^{\circ}$ toward the center of the intrusion, and the whole series has a true thickness of about $2.5 \mathrm{~km}$ (figure 2). These rocks pass upward into the Transitional Series, composed of anorthosites (sensu lato, more strictly leucogabbros, leuconorites, leucotroctolites and anorthosites), gabbros and monzogabbros (Higgins 1991; Higgins and Doig 1981; Higgins and Doig 1986). The Transitional Series is in turn overlain by monzonites, syenites, and granites of the Upper Series. There are no xenoliths of Grenville age $(>1.0 \mathrm{Ga})$ rocks in the intrusion, except immediately adjacent to the contact, and no isotopic evidence of crustal contributions to the syenites and granites of the Upper Series (Higgins and Doig 1981), suggesting that the upper parts of the intrusion did not interact with Grenville age rocks. One phase of granite in the Upper Series is loaded with finegrained enclaves considered by Loncarevic et al. (1990) to represent fragments of consanguineous volcanic rocks from the upper parts of the body. It is therefore possible that the Sept Iles intrusion formed at a high level below a series of flood basalts and more acidic volcanic rocks. Although these flood basalts have not been found north of the St Lawrence River, they could be represented by basaltic flows and clasts in the Neoproterozoic to Lower Cambrian Shickshock and Maquereau Groups of the Gaspé peninsula (Bédard and Wilson 1994; Camiré et al. 1993). Unfortunately, these units are poorly dated.

Geochronology. The sample used for geochronology was taken from a granophyric segregation in the upper part of the Layered Series. The host rock is a medium-grained $(2-3 \mathrm{~mm})$ nearly massive gabbro with black plagioclase crystals. Passage to the granophyric segregation is abrupt, and there are none of the marginal plagioclase megacrysts seen around similar structures in the anorthosite of the Transitional Series (Higgins and Doig 1981). Sparse black plagioclase crystals within the granophyric segregation are rimmed with orthoclase. However, most of the segregation is composed of separate orthoclase crystals, many of which are graphically intergrown with quartz.

Zircon crystals are relatively abundant. They are up to $1 \mathrm{~mm}$ long at pale brown in color (figure 3).

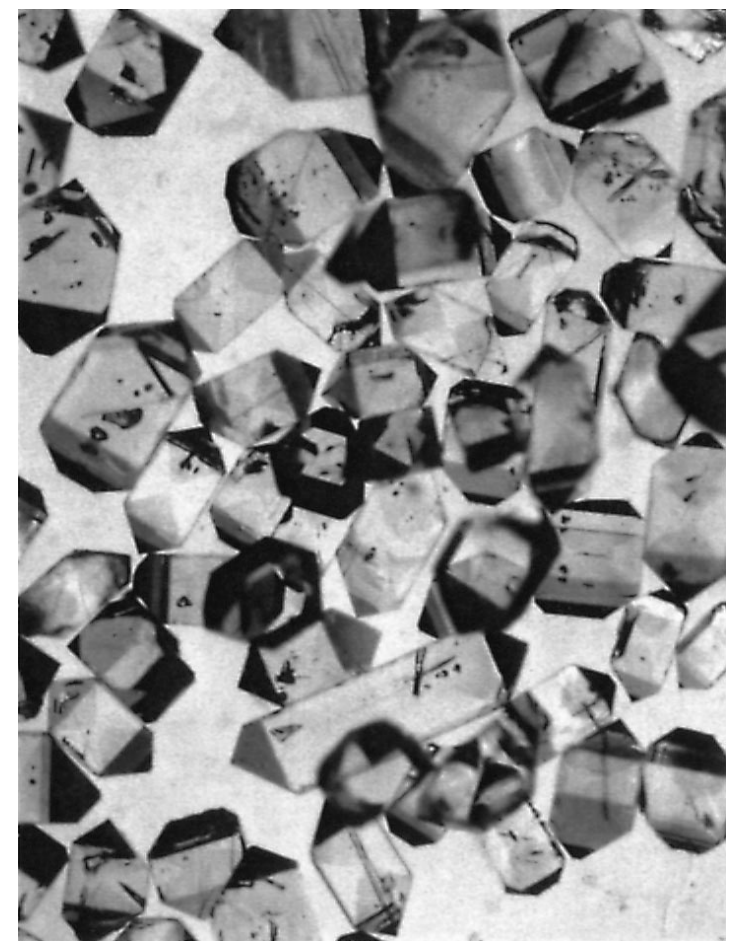

Figure 3. Photomicrograph of separated zircon crystals. Most crystals contain solid and fluid inclusions. Those selected for analysis were free of inclusions. Field of view, $3 \mathrm{~mm}$.

They have a simple euhedral form and equal development of both prismatic and pyramidal faces, with aspect ratios of $1: 2$. This morphology is thought to be indicative of high temperatures of crystallization, $\sim 900^{\circ} \mathrm{C}$, and an alkaline host magma (Pupin 1980).

Zircons were separated from the rock using conventional methods. Concordance of zircon data was enhanced by selection of clear, unaltered, unfractured grains lacking cores and prolonged airabrasion (Krogh 1982). Analytical techniques are summarized by Parrish et al. (1987), treatment of analytical errors follows Roddick (1987), and regression analysis follows York (1969). Mass discrimination for $\mathrm{Pb}$ is $0.09 \pm 0.03 \%$ per a.m.u. referenced to NBS 981. For $U$ we use a mixed ${ }^{233} \mathrm{U}^{235} \mathrm{U}$ spike from which the discrimination is calculated. Isotopic data are presented in table 1.

Three single zircon crystals were chosen for analysis. All appeared identical before abrasion, except that fraction B was smaller than the others. Uranium concentrations were surprising variable, suggesting that there is a strong zonation of $U$ in these crystals. The ratio of radiogenic to common lead, as expressed by ${ }^{206} \mathrm{~Pb} /{ }^{204} \mathrm{~Pb}$ was also very variable. Points A and D fell on the concordia and had 
Table 1. U-Pb Geochronological Data

\begin{tabular}{|c|c|c|c|c|c|c|c|c|c|c|}
\hline Fraction, size $\mathrm{e}^{\mathrm{a}}$ & $\begin{array}{l}\text { Weight } \\
\text { (mg) }\end{array}$ & $\begin{array}{c}\mathrm{U} \\
(\mathrm{ppm})\end{array}$ & $\begin{array}{c}\mathrm{Pb}^{\mathrm{b}} \\
(\mathrm{ppm})\end{array}$ & ${ }^{206} \mathrm{~Pb} /{ }^{204} \mathrm{~Pb}^{\mathrm{c}}$ & $\mathrm{Pb}^{\mathrm{d}}(\mathrm{pg})$ & $\begin{array}{l}{ }^{208} \mathrm{~Pb} \\
(\%)\end{array}$ & ${ }^{206} \mathrm{~Pb} /{ }^{238} \mathrm{U}^{\mathrm{e}}$ & ${ }^{207} \mathrm{~Pb} /{ }^{235} \mathrm{U}^{\mathrm{e}}$ & $R^{f}$ & $\begin{array}{c}{ }^{207} \mathrm{~Pb} /{ }^{206} \mathrm{~Pb} \\
\text { Model Age (Ma) }\end{array}$ \\
\hline A, $200 * 500, \mathrm{~N}-1$ & .024 & 72 & 8 & 799 & 13 & 21.9 & $.09133 \pm .15 \%$ & $.7424 \pm .29 \%$ & .55 & $565.6 \pm 1.0$ \\
\hline B $80 * 140, \mathrm{~N}-1$ & .030 & 104 & 11 & 318 & 60 & 22.5 & $.09101 \pm .15 \%$ & $.7337 \pm .61 \%$ & .62 & $547.2 \pm 2.3$ \\
\hline $\mathrm{D}, 150 * 250, \mathrm{~N}-1$ & .049 & 631 & 66 & 890 & 203 & 20.3 & $.09121 \pm .10 \%$ & $.7411 \pm .27 \%$ & .61 & $564.3 \pm 1.0$ \\
\hline
\end{tabular}

Note. All analyses were performed at the Geological Survey of Canada, Ottawa.

${ }^{\text {a }}$ Sizes in $\mu \mathrm{m}$ before abrasion, N-1 = non-magnetic cut with Frantz Isodynamic separator at $1^{\circ}$ side slope.

${ }^{\mathrm{b}}$ Radiogenic $\mathrm{Pb}$.

${ }^{\mathrm{c}}$ Measured ratio, corrected for spike and fractionation.

d Total common $\mathrm{Pb}$ in analysis corrected for fractionation and spike.

${ }^{\mathrm{e}}$ Corrected for blank $\mathrm{Pb}$ and $\mathrm{U}$, common $\mathrm{Pb}$; errors quoted are one sigma in percent.

${ }^{\mathrm{f}}$ Correlation coefficient of errors in isotope ratios.

${ }^{\mathrm{g}}$ Errors are two-sigma in million years.

the smallest error ellipses (figure 4). Point B also intersected the concordia, but had a much larger error ellipse, probably reflecting its lower ratio of radiogenic $\mathrm{Pb}$ to common $\mathrm{Pb}$. For this reason point $\mathrm{B}$ was ignored, and the age was determined from the ${ }^{207} \mathrm{~Pb} /{ }^{206} \mathrm{~Pb}$ model ages of points $\mathrm{A}$ and $\mathrm{D}$. The crystallization age, $565 \pm 4 \mathrm{Ma}$, is the weighted mean of the two $\mathrm{Pb}$ model ages.

\section{Discussion}

Timing of late Neoproterozoic and Early Cambrian Magmatism in Eastern Canada. A survey of late Neoproterozoic and early Cambrian magmatism in eastern Canada suggests that three different phases can be discerned (table 2, figure 5). The first was dominated by tholeiitic dikes, the second by alkali plutons, and the third by tholeiitic lavas. The ages of many of the plutons are poorly known, and this simple plan may have to be modified by new age data.

The earliest phase of magmatism is composed of dike swarms (figure 1; table 2). The Long Range tholeiitic dike swarm is exposed in Newfoundland and Labrador in a N-S zone over a distance of $400 \mathrm{~km}$ and has been dated at $615 \pm 2 \mathrm{Ma}$ (Kamo et al. 1989). The Grenville dike swarm extends eastward from Ontario into southern Quebec for about 700

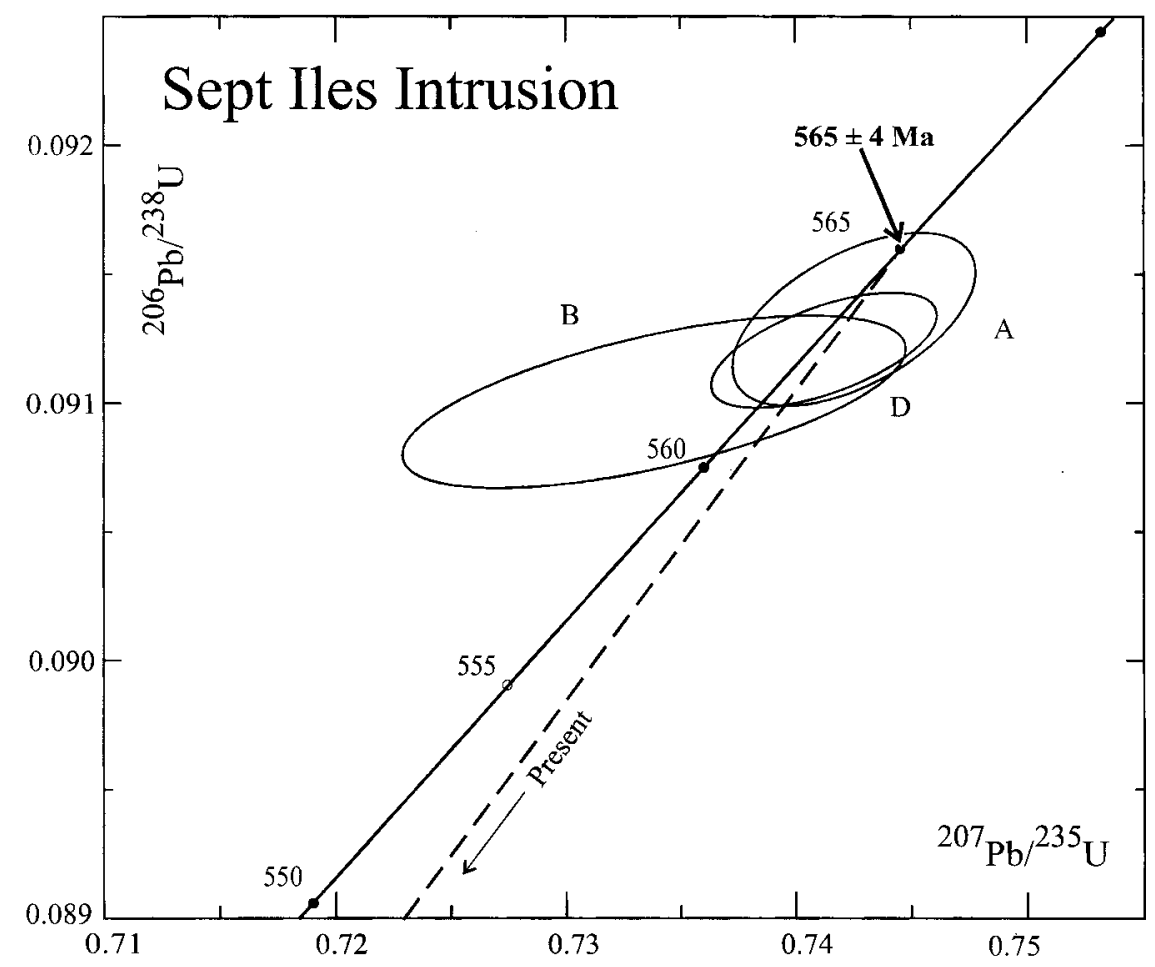

Figure 4. Concordia diagram for three fractions (A, B, and D) of zircons from a granophyric segregation in gabbro of the Layered Series, Sept Iles intrusion. The age of crystallization of the segregation is inferred to be $565 \pm 4 \mathrm{Ma}$ from the weighted mean of the $\mathrm{Pb}$ model ages of fractions $\mathrm{A}$ and $\mathrm{D}$. 
Table 2. Dated Late Precambrian and Cambrian Magmatic Rocks in Southeastern Canada

\begin{tabular}{|c|c|c|c|c|c|}
\hline Name, location & $\begin{array}{l}\text { Age (Ma): } \\
\text { method }\end{array}$ & $\begin{array}{l}\text { Dominant rock } \\
\text { types }\end{array}$ & $\begin{array}{l}\text { Geochemical } \\
\text { affinity }\end{array}$ & Form & $\begin{array}{l}\text { Volume } \\
\left(\mathrm{km}^{3}\right)\end{array}$ \\
\hline $\begin{array}{l}\text { Skinner Cove, New- } \\
\text { foundland }\end{array}$ & $550+3 /-2: \mathrm{U}^{-\mathrm{Pb}^{\mathrm{a}}}$ & Basalt & Alkali & Lavas & $?$ \\
\hline $\begin{array}{l}\text { Tibbit Hill formation, } \\
\text { Quebec }\end{array}$ & $554+4 /-2: \mathrm{U}^{-\mathrm{Pb}^{\mathrm{b}}}$ & $\begin{array}{l}\text { Basalt, comen- } \\
\text { dite }\end{array}$ & $\begin{array}{l}\text { Transitional } \\
\text { to Alkalic }\end{array}$ & $\begin{array}{l}\text { Lavas, } \\
\text { tuffs }\end{array}$ & 16,000 \\
\hline $\begin{array}{l}\text { Rigaud intrusion, } \\
\text { Quebec }\end{array}$ & $563 \pm 14: \mathrm{U}-\mathrm{Pb}^{\mathrm{c}}$ & Granite, syenite & Alkalic & Pluton & $?$ \\
\hline $\begin{array}{l}\text { Sept Iles intrusion, } \\
\text { Quebec }\end{array}$ & $565 \pm 4: \mathrm{U}-\mathrm{Pb}^{\mathrm{d}}$ & $\begin{array}{l}\text { Gabbro, anortho- } \\
\text { site, granite }\end{array}$ & Alkalic & Pluton & 20,000 \\
\hline $\begin{array}{l}\text { Buckingham lavas, } \\
\text { Quebec }\end{array}$ & $573 \pm 32: \mathrm{K}-\mathrm{Ar}^{\mathrm{e}}$ & $\begin{array}{l}\text { Trachyandesite } \\
\text { lavas }\end{array}$ & Alkalic & Lavas & Small \\
\hline $\begin{array}{l}\text { St Honoré intrusion, } \\
\text { Quebec }\end{array}$ & 574: K-Ar ${ }^{\mathrm{f}, \mathrm{g}}$ & $\begin{array}{l}\text { Nepheline } \\
\text { syenite, car- } \\
\text { bonatite }\end{array}$ & Alkalic & Pluton & 150 \\
\hline $\begin{array}{l}\text { Lake Nipissing alkalic } \\
\text { province, Ontario }\end{array}$ & $\begin{array}{l}\text { 575: K-Arg } \\
577 \pm 1: \mathrm{U}^{\mathrm{g}} \mathrm{Pb}^{\mathrm{h}}\end{array}$ & Syenite & Alkalic & Plutons & 60 \\
\hline $\begin{array}{l}\text { Mutton Bay intrusion, } \\
\text { Quebec }\end{array}$ & 578: K-Arg & Syenite & Alkalic & Pluton & 900 \\
\hline Grenville dikes, Ontario & $590+2 /-1: \mathrm{U}^{-\mathrm{Pb}^{\mathrm{h}}}$ & Diabase & Tholeiitic & Dikes & $?$ \\
\hline $\begin{array}{l}\text { Long Rand dikes, } \\
\text { Newfoundland }\end{array}$ & $615 \pm 2: \mathrm{U}^{-\mathrm{Pb}^{\mathrm{i}}}$ & Diabase & Tholeiitic & Dikes & $?$ \\
\hline $\begin{array}{l}\text { a McCausland et al. } 1997 . \\
\text { b Kumarapeli et al. } 1989 . \\
\text { c Malka et al. } 1996 . \\
\text { d This paper. } \\
\text { e Lafleur } 1981 .\end{array}$ & \multicolumn{2}{|c|}{$\begin{array}{l}\text { f Doig and Barton } 1968 . \\
{ }^{\mathrm{g}} \text { Doig } 1970 . \\
\text { h Kamo et al. } 1995 . \\
{ }^{\mathrm{h}} \text { Kamo et al. } 1989 .\end{array}$} & & & \\
\hline
\end{tabular}

$\mathrm{km}$ (figure 1). Most dikes are tholeiitic with some minor transitional compositions. Kamo et al. (1995) dated three dikes and concluded that the age of the swarm was $590+2 /-1 \mathrm{Ma}$. Unmetamorphosed diabase dikes in the Grenville Province between the Long Range and Grenville swarms are much rarer (e.g., LaFlèche et al. 1993) and have not been studied in detail. Kumarapeli (1993) considered that the Ottawa graben system was formed synchronously with the Grenville dike swarm. However, the orientation of these two structures differs by up to $30^{\circ}$; hence there must be some difference in age, although it might be quite small.

The second magmatic phase is composed of dominantly alkaline plutons emplaced over a large region during a relatively short period of time (figures 1, 5; table 2). Doig (1970) first noted that the $\mathrm{K}$-Ar age of many carbonatites and alkali intrusions in eastern North America, Greenland, and Scandinavia fell within analytical error of $575 \mathrm{Ma}$ (all $\mathrm{K}-\mathrm{Ar}$ ages have been corrected using the isotopic parameters of Steiger and Jager 1977). In eastern Canada the St-Honoré carbonatite/syenite complex gave a K-Ar age of $574 \mathrm{Ma}$ (Doig and Barton 1968), and the Mutton Bay syenite intrusion gave a K-Ar age of $578 \mathrm{Ma}$ (Doig and Barton 1968). The Lake Nipissing alkaline province (Lumbers 1971) comprises seven different alkali intrusions, most of which are undated. A compilation of data by $\mathrm{Ku}-$ marapeli (1993) suggested an age of $575 \mathrm{Ma}$, which is confirmed by a $\mathrm{U} / \mathrm{Pb}$ zircon age of $577 \pm 1 \mathrm{Ma}$ (mentioned in Kamo et al. 1995). Trachyandesite lavas near Buckingham, Quebec have a K-Ar age of $573 \pm 32 \mathrm{Ma}$ (Lafleur and Hogarth 1981). The granite-syenite intrusion at Rigaud, Quebec has been dated by U-Pb methods at $563 \pm 14 \mathrm{Ma}$ (Malka et al. 1996). We have shown above that the age of the Sept Iles intrusion, $565 \pm 4 \mathrm{Ma}$, makes it a late, but volumetrically important, component of this widespread event.

The volumetrically most important component of the last phase is the Tibbit Hill formation in the Appalachian region of Quebec (figure 1; table 2). This unit is dominated by mafic lavas and is considered to mark the rift-drift transition in this region (Kumarapeli 1993; Kumarapeli et al. 1989). The upper part of this unit contains comendites dated by $\mathrm{U} / \mathrm{Pb}$ zircon methods at $554+4 /-2 \mathrm{Ma}$, but the lower parts could be as much as $5 \mathrm{~m}$.y. older (Kumarapeli et al. 1989).

Elsewhere in the northern Appalachians there are other volcanic rocks considered to be late Neoproterozoic to Early Cambrian age, on the basis of isotope geochronology or stratigraphic correlations. These include diabase dikes on the Appalachian foreland, northeast of Quebec City, and 


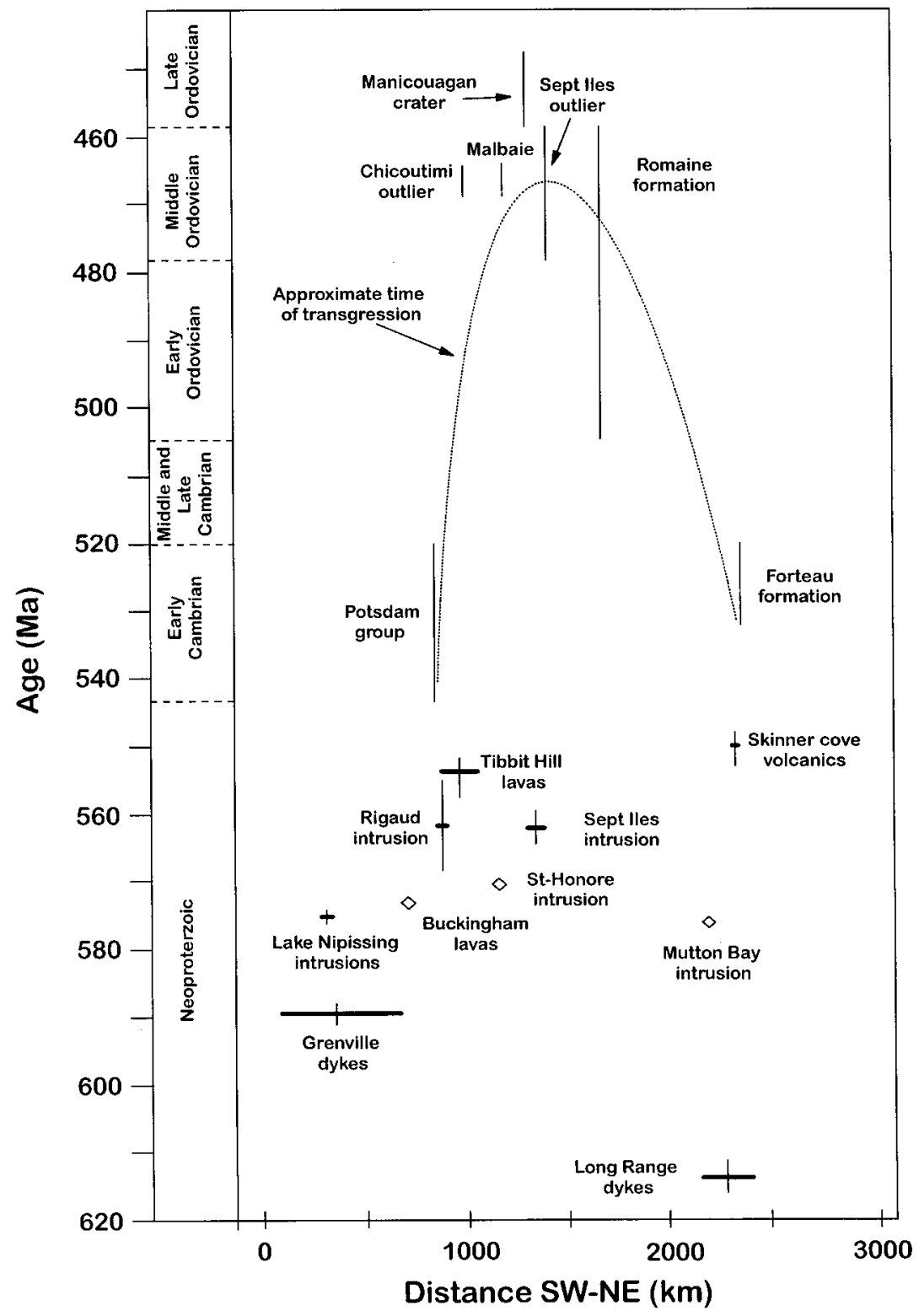

Figure 5. Ages of Neoproterozoic and Cambrian magmatic rocks, and platform sediments in southeastern Canada. For the U-Pb mineral ages the horizontal line is the SW-NE extent, and the vertical line is the uncertainty in the age (Kamo et al. 1989, 1995; Kumarapeli et al. 1989; this paper). The diamonds are K-Ar ages (Doig 1970; Doig and Barton 1968). No errors were indicated for most of these dates. References for the ages of the sediments are indicated in the text. The vertical lines represent the uncertainty in the age of the units, as well as their duration. The upper and lower boundaries of the Early Cambrian period are from Grotzinger et al. (1995). Other boundaries are from Harland (1990).

metabasaltic flows and clasts in sedimentary rocks of the Montagne de St-Anselme formation (LaFlèche et al. 1993), the Chaudière River nappe and Drummondville Olistostrome (Vermette et al. 1993), the Maquereau group (Bédard and Wilson 1994), and the Shickshock group (Camiré et al. 1993) and other minor tectonic slices. The position of these rocks within the scheme proposed here must await precise determinations of their ages. Minor alkali volcanic rocks at Skinners Cove, Newfoundland, have been dated at $550+3 /-2 \mathrm{Ma}$ by U-Pb methods (McCausland et al. 1997), placing them firmly in the third phase of magmatism.

Plume Tectonics. It is now widely accepted that much voluminous, short-lived, continental magmatism is related to plumes that rise from deep in the mantle, but the details of the processes are still unclear (Hill et al. 1992). Two main camps have evolved: White and McKenzie (1989) proposed that relatively narrow mantle plumes rise up from the base of the upper mantle at $670 \mathrm{~km}$ and pond hot material below the lithosphere over a period of perhaps $50 \mathrm{~m}$.y. to generate thermal anomalies 1000 to $2000 \mathrm{~km}$ in diameter. Where these thermal anomalies are intersected by continental rifts, massive igneous activity occurs, generally in the form of flood basalts. In some cases rifting soon leads to drifting and the creation of new plate margins. Campbell and Griffiths (1990) proposed a different model. The plume starts at the core-mantle boundary and entrains adjacent mantle material as it rises, yielding a bulbous head dominated by en- 
trained material and a narrow tail of lower mantle material. In this model the plume heads can produce magmatism in a short period over regions $1000-2000 \mathrm{~km}$ in diameter. If the lithosphere containing continental crust moves with respect to the plume then the magmatism produced by the plume tails will be confined to linear tracks $100-300 \mathrm{~km}$ wide, provided the magmas can break through the crust. In this case continental break-up does not necessarily follow magmatism. In both models the crust above the plume is uplifted due to thermal expansion of the lithosphere to form a broad dome. The uplift can persist for a long period of time, unless there is crustal thinning by extension.

There are several options for the age and location of the plume or plumes that may have produced the magmatism summarized in this paper. The large volume of the Tibbit Hill lavas (table 2), their spatial relationship to the Ottawa graben and Grenville dikes, the chemistry of the different rocks, and the approximate concordance of their ages suggested to Kumarapeli (1993) that a simple plume model could be applied. He proposed that a mantle plume was located beneath the pre-transport position of the Tibbit Hill region from 590 to $554 \mathrm{Ma}$. Over the center a RRR triple junction was established, two branches of which subsequently developed into a margin of the Iapetus Ocean. However, the new geochronologic evidence presented here indicates that the Sept Iles intrusion was emplaced after the Grenville dike swarm and before the Tibbit Hill volcanism. The role of this intrusion cannot be neglected, as its volume is similar to that of the Tibbit Hill lavas (Kumarapeli et al. 1981), and it is only $500 \mathrm{~km}$ away (table 2; figure 1). It is therefore proposed that a major mantle plume arrived at the base of the lithosphere at about $565 \mathrm{Ma}$ beneath Sept Iles, or to the SE. The Tibbit Hill and other lavas exposed in the Appalachians were then formed during the later stages of this plume.

A mantle plume this large and long-lived should have a significant effect on the height of the land surface (Campbell and Griffiths 1990). We are fortunate that most of this region was exposed during the late Neoproterozoic. The transgression of the sea onto the craton is recorded by sediments mostly deposited directly on the Neoproterozoic basement (Grenville age rocks), and largely preserved along the edge of the St Lawrence valley (figures 1,5). Near Montreal the lowest parts of the Potsdam group are thought to be Early Cambrian, although they are unfossiliferous, because they are overlain by Late Cambrian sediments (Globensky 1987). Farther east the earliest sediments near Chicoutimi are mid-Middle Ordovician, as are those at Malbaie (Desbiens and Lespérance 1989). The oldest lime- stones preserved within the Manicouagan crater are slightly younger, lower Upper Ordovician (Desbiens and Lespérance 1989). The Sept Iles intrusion itself is covered with Middle Ordovician limestones (Loncarevic et al. 1990). The lowest unit of the sediments that crop out on the Mingan Islands, the Romaine formation, was deposited in Early Ordovician time (Globensky 1993). Farther east, near the Strait of Belle Isle, the platform cover is a little more complex, but the Forteau formation appears to record a transgression in late Early Cambrian time (Williams and Hiscott 1987). Such a pattern of transgression is consistent with crustal doming centered near Sept Iles that started before the early Cambrian (figure 5). This dome had subsided by Middle Ordovician time, when the eroded top of the Sept Iles intrusion was submerged. If the dome was initiated synchronously with the emplacement of the Sept Iles intrusion then subsidence must have taken about 80 m.y., a period consistent with the plume model of Campbell and Griffiths (1990).

If a plume was centered near Sept Iles and arrived in the lithosphere toward the end of the Neoproterozoic, how much of the earlier magmatism could have been associated with it? Many authors have suggested that a main plume magmatism is preceded by minor volatile-rich magmatism (e.g., Hill 1991). Certainly the Nipissing, St-Honoré, and Mutton Bay intrusions, the Buckingham volcanics, and the widespread lamprophyre dikes (Doig 1970) could be accommodated in this type of model (figure 5). The Grenville and Long Range dikes swarms were emplaced 26 and 51 m.y. before the main Sept Iles event, approximately within the $50 \mathrm{~m}$.y. accumulation period of White and McKenzie (1989) type plumes. However, these dikes are dominantly tholeiitic or transitional, which does not fit well with such a model.

Another possibility is that the dike swarms were produced by separate plumes of the type envisaged by Campbell and Griffiths (1990). The Long Range plume would have arrived at the base of the lithosphere at $615 \mathrm{Ma}$; the limited extent of the swarm implies that it was small or perhaps only the tail of a plume. Dike swarms can be emplaced laterally over large distances (e.g., Mackenzie dike swarm; LeCheminant and Heaman 1989); hence the plume did not have to be located beneath the present swarm (White and McKenzie 1995) and could have even risen up the path later used by the Sept Iles plume. Following the same model, the Grenville dike swarm could have been formed by a larger plume some 25 m.y. later. Again, the dikes could have propagated laterally from a plume thousands of kilometers away, perhaps again close to Sept Iles. 
Bercovici and Mahoney (1994) observed that many flood basalt provinces are bimodal in time with 20-90 m.y. separating the phases, rather like the region studied here. They proposed that a plume originating at the base of the lower mantle could become separated from its tail when it passed from the higher viscosity of the lower mantle to the lower viscosity of the upper mantle. The main plume would continue toward the surface, whilst the tail would form a secondary plume, rising to the base of the lithosphere sometime later. Application of such a model would suggest that the dike swarms at 615 and $590 \mathrm{Ma}$ represent the plume head, and the $565 \mathrm{Ma}$ "event" was produced by the secondary plume.

Another possibility is suggested by recent research on the structure of the subcontinental lithosphere. Seismic velocity anomalies beneath extinct volcanic fields suggest that anomalously hot cylinders, produced initially by the transport of magma, can persist for up to 180 m.y. (Stein and Hofmann 1992; VanDecar et al. 1995). We propose that if such a structure was established by the magmatism at $615 \mathrm{Ma}$, then as the continental crust and its attached lithosphere moved over the asthenosphere, the structure would act as a conduit, allowing plumes to penetrate more readily into the lithosphere.

\section{Conclusions}

There were three phases of magmatism in southeastern Canada during late Neoproterozoic and Cambrian time. The first phase was composed of two tholeiitic dike swarms of uncertain origin. They may have been produced by one or two mantle plumes between 615 and $590 \mathrm{Ma}$. These plume or plumes could have been located anywhere in this region, perhaps even coincident with the proposed later Sept Iles plume.

The next magmatic phase was dominated by alkalic plutons emplaced along rift faults that developed after the diking events. This phase of magmatism was probably produced by a major plume located near Sept Iles or to the southeast. The arrival of the plume in the lithosphere was indicated by minor but widespread alkali plutonism. The most important magmatism was the large Sept Iles layered mafic intrusion. A crustal dome centered on Sept Iles developed then and persisted for 80 m.y. The final phase of magmatism was dominated by lavas and probably accompanied the earliest stages of formation of the Iapetus Ocean.

\section{ACKNOWLEDGMENT}

We would like to thank colleagues in Science de la Terre, UQAC, and the Geochronology Laboratory of the Geological Survey of Canada for their advice and help, particularly the comments of Tony LeCheminant (GSC), Richard Ernst (GSC) and Pierre Cousineau (UQAC). Daniel Brisebois, Ministère des Ressources naturelles du Québec, suggested the link between sedimentation and the Sept Iles intrusion. This research was partly funded by operating grants from the Natural Science and Engineering Research Council of Canada to $\mathrm{MDH}$. Geological Survey of Canada contribution number 1997202.

\section{REFERENCES CITED}

Aleinikoff, J. N.; Zartman, R. E.; Walter, M.; Rankin, D. W.; Lyttle, P. T.; and Burton, W. C., 1995, U-Pb ages of metarhyolites of the Catoctin and Mount Rogers formations, Central and Southern Appalachians; evidence for two pulses of Iapetan rifting: Am. Jour. Sci., v. 295 , p. $428-454$.

Ashwal, L. D., 1993, Anorthosites and Related Rocks: Berlin, Springer-Verlag, $422 \mathrm{p}$.

Bédard, J. H., and Wilson, C., 1994, Maquereau group lavas, southern Gaspésie, Quebec Applachians: Cur. Res. 1994-D, Geol. Survey Canada, p. 143-154.

Bercovici, D., and Mahoney, J., 1994, Double flood basalts and plume head separation at the 660-kilometer discontinuity: Science, v. 266, p. 1367-1369.

Bond, G. C.; Nickeson, P. A.; and Kominz, M. A., 1984, Breakup of a supercontinent between $625 \mathrm{Ma}$ and $555 \mathrm{Ma}$ : New evidence and implications for continental histories: Earth Planet. Sci. Lett., v. 70, p. 325-345.
Camiré, G.; La Fléche, M. R.; and Malo, M., 1993, Géochimie des roches volcaniques cambro-ordoviciennes du groupe de Shickshock: Incidences sur le contexte géotectonique de la Gaspésie septentrionale: Rech. en cours, Partie E, Com. géol. Canada, v. 93-1E, p. 281290.

Campbell, I. H., and Griffiths, R. W., 1990, Implications of mantle plume structure for the evolution of flood basalts: Earth Planet. Sci. Lett., v. 99, p. 79-93.

Desbiens, S., and Lespérance, P. J., 1989, Stratigraphy of the Ordovician of the Lac-St-Jean and Chicoutimi outliers, Quebec: Can. Jour. Earth Sci., v. 26, p. 11851202.

Doig, R., 1970, An alkaline rock province linking Europe and North America: Can. Jour. Earth Sci., v. 7, p. 2228.

Doig, R., and Barton, J. M., 1968, Ages of carbonatites and other igneous rocks in Quebec: Can. Jour. Earth Sci., v. 5, p. 1401-1407. 
Geological Survey of Canada, 1969, Sept Iles, Quebec. Aeromagnetic Series Map 7362G. Scale 1:253440.

Globensky, Y., 1987, Géologie des Basses-Terres du Saint-Laurent: Ministère de l'Energie et des Ressources du Quebec, MM 85-02, 69 p.

,- 1993 , Lexique stratigraphique canadien Volume V-B, Region des Appalaches, des Basses-Terres du Saint-Laurent et des iles de la Madeleine; Ministère de 1'Energie et des Ressources du Quebec, DV 91-23, $333 \mathrm{p}$.

Grotzinger, J. P.; Bowring, S. A.; Saylor, B. Z.; and Kaufman, A. J., 1995, Biostratigraphic and geochronologic constraints on early Cambrian evolution: Science, v. 270, p. 598-604.

Harland, W. B., 1990, A revised geologic timescale 1989: Cambridge, Cambridge University Press, 422 p.

Higgins, M. D., 1991, The origin of laminated and massive anorthosite, Sept Iles intrusion, Quebec, Canada: Contrib. Mineral. Petrol., v. 106, p. 340-354.

Higgins, M. D., and Doig, R., 1977, 540 Myr-old anorthosite complex in the Grenville province of Quebec, Canada: Nature, v. 267, p. 40-41.

, and — 1981, The Sept Iles anorthosite complex: Field relationships, geochronology, and petrology: Can. Jour. Earth Sci., v. 18, p. 561-573.

$\longrightarrow$, and $\longrightarrow$ 1986, Geochemical constraints on the processes that were active in the Sept Iles complex: Can. Jour. Earth Sci., v. 23, p. 670-681.

Hill, R. I., 1991, Starting plumes and continental breakup: Earth Planet. Sci. Lett., v. 104, p. 398-416.

—; Campbell, I. H.; Davies, G. F.; and Griffiths, R. W., 1992, Mantle plumes and continental tectonics: Science, v. 256, p. 186-193.

Ilyin, A. V., 1990, Proterozoic supercontinent, its latest Precambrian rifting, breakup, dispersal into smaller continents, and subsidence of their margins: Evidence from Asia: Geology, v. 18, p. 1231-1234.

Kamo, S. L.; Gower, C. F.; and Krough, T. E., 1989, Birth date for the Iapetus Ocean? A precise U-Pb and baddeleyite age for the Long Range dikes, southeast Labrador: Geology, v. 17, p. 602-605.

—; Krogh, T. E.; and Kumarapeli, P. S., 1995, Age of the Grenville dike swarm, Ontario-Quebec: Implications for the timing of Iapetan rifting: Can. Jour. Earth Sci., v. 32, p. 273-280.

Krogh, T. E., 1982, Improved accuracy of U-Pb zircon ages by creation of more concordant systems using an air abrasion technique: Geochim. Cosmochim. Acta, v. 37, p. 637-649.

Kumarapeli, P. S., 1993, A plume-generated segment of the rifted margin of Laurentia, southern Canadian Appalachians, seen through a completed Wilson cycle: Tectonophysics, v. 219, p. 47-55.

—; Dunning, G. R.; Pintson, H.; and Shaver, J., 1989, Geochemistry and $\mathrm{U}-\mathrm{Pb}$ zircon age of comenditic metafelsites of the Tibbit Hill formation, Quebec Appalachians: Can. Jour. Earth Sci., v. 26, p. 1374-1383. ; Goodacre, A. K.; and Thomas, M. D., 1981, Gravity and magnetic anomalies of the Sutton Mountains region, Quebec and Vermont: Expressions of rift vol- canics related to the opening of Iapetus: Can. Jour. Earth Sci., v. 18, p. 680-692.

—, and Saull, V. A., 1966, The St. Lawrence Valley system: A North American equivalent of the East African rift system: Can. Jour. Earth Sci., v. 3, p. 639657.

LaFlèche, M. R.; Schrijver, K.; and Tremblay, A., 1993, Geochemistry, origin, and provenance of upper Proterozoic to upper Cambrian alkaline to transitional basaltic rocks in and contiguous to a sector of the Appalachian Humber zone, Canada: Am. Jour. Sci., v. 293, p. 980-1009.

Lafleur, J., and Hogarth, D. D., 1981, Cambro-Proterozoic volcanism near Buckingham, Quebec: Can. Jour. Earth Sci., v. 18, p. 1817-1823.

LeCheminant, A. N., and Heaman, L. M., 1989, Mackenzie igneous events, Canada: Middle Proterozoic hotspot magmatism associated with ocean opening: Earth Planet. Sci. Lett., v. 96, p. 38-48.

Loncarevic, B. D.; Feininger, T.; and Lefebvre, D., 1990, The Sept-Iles layered mafic intrusion: Geophysical expression: Can. Jour. Earth Sci., v. 27, p. 501-512.

Lumbers, S. B., 1971, Geology of the North Bay area, Districts Nipissing and Parry Sound: Ontario Dept. Mines Rept. 94, 112 p.

Malka, E.; Stevenson, R. K.; and David, J., 1996, The petrology and petrogenesis of the Mt. Rigaud alkaline syeno-granite, Quebec: Geol. Assoc. Canada Prog. with Abs., v. 21, p. A-61.

McCausland, P. J. A.; Hodych, J. P.; and Dunning, G. R., 1997, Evidence from western Newfoundland for the final breakup of Rodonia?: U-Pb age and palaeolatitude of the Skinner cove volcanics: Geol. Assoc. Canada Prog. with Abs., v. 22, p. A-99.

Parrish, R. R.; Roddick, J. C.; Loveridge, W. D.; and Sullivan, R. W., 1987, Uranium-lead analytical techniques at the geochronology laboratory, Geological Survey of Canada, radiogenic age and isotope studies: Report 1: Geol. Survey Canada, Paper 87-2, p. 3-7.

Piper, J. D. A., 1976, Palaeomagnetic evidence for a Late Proterozoic Supercontinent: Royal Soc. (London) Philos. Trans.: v. 280A, p. 469-490.

Pupin, J. P., 1980, Zircon and granite petrology: Contrib. Mineral. Petrol., v. 73, p. 207-220.

Roddick, J. C., 1987, Generalized numerical error analysis with application to geochronology and thermodynamics: Geochim. Cosmochim. Acta, v. 51, p. 359362.

Steiger, R. H., and Jager, E., 1977, Subcommission on geochronology; Convention on the use of decay constants in geo- and cosmochronology: Earth Planet. Sci. Lett., v. 36, p. 359-362.

Stein, M., and Hofmann, A. W., 1992, Fossil plume head beneath the Arabian lithosphere: Earth Planet. Sci. Lett., v. 114, p. 193-209.

Stockmal, G. S.; Colman-Sadd, S. P.; Keen, C. E.; O’Brian, S. J.; and Quinlan, G., 1987, Collision along an irregular margin: A regional plate tectonic interpretation of the Canadian Appalachians: Can. Jour. Earth Sci., v. 24, p. $1098-1107$. 
VanDecar, J. C.; James, D. E.; and Assumpçao, M., 1995, Seismic evidence for a fossil mantle plume beneath South America and implications for plate driving forces: Nature, v. 378, p. 25-31.

Vermette, D. R.; Hébert, R.; and Bergeron, M., 1993, Petrological and geochemical characteristics related to early rifting of Iapetus Ocean, Québec Appalachians: Am. Jour. Sci., v. 293, p. 81-110.

White, R., and McKenzie, D., 1989, Magmatism at rift zones: The generation of volcanic continental margins and flood basalts: Jour. Geophys. Res., v. 94, p. 76857729.
White, R. S., and McKenzie, D., 1995, Mantle plumes and flood basalts: Jour. Geophys. Res., v. 100, p. 17,54317,586 .

Williams, H., and Hiscott, R. N., 1987, Definition of the Iapetus rift-drift transition in western Newfoundland: Geology, v. 15, p. 1044-1047.

York, D., 1969, Least-squares fitting of a straight line with correlated errors: Earth Planet. Sci. Lett., v. 5, p. 320-324. 
